\title{
The monetary approach to exchange rate determination: empirical observations from the Pacific Basin economies
}

\author{
Chinh Le Huy ${ }^{a^{*}}$ and Huyen Le Hoang Ba
}

${ }^{a}$ Faculty of Economics and Business Administration, Hong Duc University, Vietnam

\begin{tabular}{l}
\hline C H R O N I C L E \\
\hline Article history: \\
Received January 2, 2020 \\
Received in revised format: \\
January 28, 2020 \\
Accepted February 26, 2020 \\
Available online \\
February 27, 2020 \\
\hline Keywords: \\
Pacific Basin \\
Vietnam \\
Monetary model \\
Exchange rate \\
Cointegration
\end{tabular}
\begin{abstract}
A B S T R A C T
The paper studies the monetary approach to exchange rate for a group of five Pacific Basin economies, using quarterly data for the period of post - Asian financial crisis. Estimated results reveal that for Thailand and the Indonesia which were most affected by Asian financial crisis, monetary model did not work for explaining exchange rate movements. For Korea and Malaysia, the results show that there were long-run relationships between exchange rates and their monetary variables. However, the proportionality hypothesis of exchange rate to relative money supply did not hold for the two countries. Conversely, for Vietnam, it appears that the monetary model worked well in explaining exchange rate movements. Especially, the estimated coefficients of money and output variables are consistent with any traditional variants of monetary model.
\end{abstract}

\section{Introduction}

There are several different approaches to exchange rate determination. Among them, the monetary approach to exchange rate (MAER) has attracted attention in the study of exchange rate for a long time. MAER has been also analyzed and modelled from two main different perspectives. The first one is flexible-price model, developed by Frenkel (1976) and Bilson (1978). The second monetary approach to exchange rate determination is sticky-price model, developed by Dornbusch (1976) and Frankel (1979). There are many debates about the effectiveness of monetary model to forecast the exchange rate movement. Meese and Rogoff (1983) suggested that standard monetary models of exchange rate determination possess rather weak explanatory power and a simple random walk model for exchange rates can beat various time series and structural models in terms of out-of-sample forecasting performance. Moreover, studies by Meese (1986) and by Baillie and Selover (1987) were unable to discover the long-run relationship between exchange rate and its monetary variables. According to Boothe and Glassman (1987), previous studies have no tools for testing long-run exchange rates. Also, recent studies also negates the MAER (Cheung et al., 2005; Engel, 2007; Faust, 2003; Rapach \& Wohar, 2002). Furthermore, Alvarez et al. (2007) argued that if exchange rates follow random walks, then a revision of the monetary theoretical models is necessary.

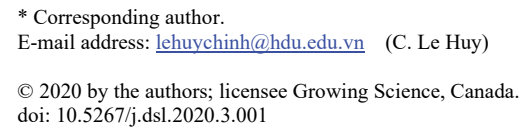


On the other hand, following decades of failure to empirically explain and forecast fluctuations in exchange rates determination by monetary models, throughout 1990s, succeeding works by Mark (1995) and by Chinn and Meese (1995) and series studies, which employed cointegration technique, by MacDonand and Taylor ((1991); (1993); (1994a); (1994b)) overturned the of Meese and Rogoff's hypothesis. Since then, monetary model of exchange rate determination has attracted considerable interest and researchers found positive results throughout the world. For instance, in Europe, studies by Diamandis et al. (1998), Frenkel and Koske (2004), Tawadros (2008), Uz and Ketenci (2008), and Papadamou and Markopoulos (2012) provided the empirical validity of monetary models in explaining exchange rates. Furthermore, in United States of America, the monetary models is found to be effective in forecasting exchange rate movements (Cushman, 2007; Hwang, 2001; Kouretas, 1997; Loría et al., 2010). The validity of monetary model of exchange rate is pointed out in Africa (Evans, 2013).

Empirical studies of MAER for Asian economies also provided positive results. Liew et al. (2009) investigated MAER for Thailand bath-Japanese yen exchange rate. The findings showed the existence of relationship between exchange rate and fundamental variables. Furthermore, some popular restrictions are valid. Similarity, Chin et al. (2007a) examined the long-run validity of monetary model for the Malaysian ringgit - U.S dollar. The result represented a long-run relationship exists between variables in the model for the ringgit-U.S dollar exchange rate. In addition, coefficients of money and output differentials are consistent with flexible-price and sticky-price models as well. In particular, the results are highly consistent with Bilson's monetary model. Another study by Chin el al. (2007b) also indicates that fundamental variables explain adequately the determination of Philippines peso-U.S dollar exchange rate even if the hypothesis of proportionality between exchange rate and money does not hold. Miyakoshi (2000) investigated of the monetary model for the case of the Korean won German mark, the Korean won - Japanese yen, and Korean won - US dollar for the period of pre-Asian financial crisis. The findings pointed out that the long-run relationship between exchange rate and monetary fundamentals is valid for all cases. The study by Makrydakis (1998) also reported the validity of monetary model of exchange rate determination for Korean won- U.S dollar during the period of 1980-1995.

In this paper, for the first time, the monetary model of exchange rate determination is re-examined for group of five Pacific Basin countries (Vietnam, Thailand, Malaysia, Indonesia, and Korea), using quarterly data for the period of post-Asian financial crisis. For this purpose, the multivariate cointegration techniques are employed and various restrictions such as monetary restrictions and

exclusion restrictions are performed. More specifically, the dynamic forecast for exchange rate is carried out by simulating VARs method.

The rest of the paper is structured as follows. Section 2 presents monetary model and methodology. The data description and estimated results are expressed in section 3. Section 4 provides discussions. The following section concludes the paper.

\section{The monetary model and econometric methodology}

The monetary model of exchange rate determination can be expressed compactly following the reduced form equation ${ }^{1}$

$$
\delta_{o} s_{t}=\delta_{1} m_{t}+\delta_{2} m_{t}^{*}+\delta_{3} y_{t}+\delta_{4} y_{t}^{*}+\delta_{5} r_{t}+\delta_{6} r_{t}^{*}+u_{t}
$$

where $s_{t}$ is the spot exchange rate (defined as the price of a unit foreign money in terms of domestic money), $m_{t}$ is the domestic money supply, $y_{t}$ is the domestic real output, $r_{t}$ is the domestic interest rate, corresponding foreign magnitudes are denoted by an asterisk, $u_{t}$ is a disturbance term. The scheme of E.q (1) nests both flexible-price version as well as sticky-price model. The literature suggests that if

\footnotetext{
${ }^{1}$ See MacDonald and Taylor (1991), MacDonald and M.P (1994a), Diamandis and Kouretas (1996); Makrydakis (1998);
} Miyakoshi (2000); Liew, Baharumshah et al. (2009) for further information. 
the model is correct, it is expected thatthe coefficients $\delta_{1}$ and $\delta_{2}$ should equal +1 and -1 respectively (of course, $\delta_{0}=1$ ), a rise in money supply from a country out of the group Pacific Basin economies (US) is expected to cause the depreciation (appreciation) of Pacific Basin' currencies (Vietnamese dong, Thai Baht, Korea Won, Indonesia rupiah, and Malaysia Ringgit respectively). In addition, $\delta_{3}$ and $\delta_{4}$ should, in turn, be negative and positive $\left(\delta_{3}<0\right.$ and $\left.\delta_{4}>0\right)$. Finally, the selected Asian countries' (US) interest rate should play a positive (negative) impact on the exchange rate $\left(\delta_{5}>0 \text { and } \delta_{6}<0\right)^{2}$.

Referring to the literature review, if cointegration vectors exist, some commonly monetary restrictions and tests of exclusion restrictions are performed to check whether these relationships between exchange rate and fundamental values are consistent with theoretical issues. In terms of monetary restrictions, the most important of these parameter restrictions is the existence of the proportionality between exchange rate and its relative money $\left(H_{1}: \delta_{0}=\delta_{1}=-\delta_{2}\right)$. Less significant for the validity of the monetary model, yet also frequently imposed and tested, are equal and opposite coefficients on relative outputs $\left(H_{2}: \delta_{3}+\delta_{4}=0\right)$ and interest rates $\left(H_{3}: \delta_{5}+\delta_{6}=0\right)$. Furthermore, the other null hypotheses are to test the joint significance of the some of the combined effects of the first three restrictions $\left(H_{4}: H_{1} \cap H_{2} ; H_{5}: H_{1} \cap H_{3} ; H_{6}: H_{2} \cap H_{3} ; H_{7}: H_{1} \cap H_{2} \cap H_{3}\right)$. More strictly, the findings have to be supported by tests of exclusion restrictions on exchange rate, money, output and interest rates $\left(H_{8}: \delta_{0}=\right.$ $\left.0 ; H_{9}: \delta_{1}=\delta_{2}=0 ; H_{10}: \delta_{3}=\delta_{4}=0 ; H_{11}: \delta_{5}=\delta_{6}=0\right)$. The null hypothesis $H_{8}$ tests whether exchange rate is a part of model. $H_{9}$ examines the meaning of money supply and $H_{10}$ test the validity of output in forming the monetary model. The $H_{11}$ test will suggest that the interest rate is qualified to take into account in the model or not. Table 1 summarizes monetary and exclusion restrictions will be tested.

Table 1

Tests of exclusion restriction and monetary restriction

\begin{tabular}{lr}
\hline & Monetary restrictions \\
$H_{1}: \delta_{0}=\delta_{1}=-\delta_{2}$ & $H_{5}: H_{1} \cap H_{3}$ \\
$H_{2}: \delta_{3}+\delta_{4}=0$ & $H_{6}: H_{2} \cap H_{3}$ \\
$H_{3}: \delta_{5}+\delta_{6}=0$ & $H_{7}: H_{1} \cap H_{2} \cap H_{3}$ \\
$H_{4}: H_{1} \cap H_{2}$ & \\
& Exclusion restrictions \\
$H_{8}: \delta_{0}=0$ & $H_{10}: \beta_{3}=\beta_{4}=0$ \\
$H_{9}: \delta_{1}=\delta_{2}=0$ & $H_{11}: \beta_{5}=\beta_{6}=0$ \\
\hline
\end{tabular}

To investigate the long-run relationship between the variables in the model, we use Johansen's procedure ( Johansen, 1988; Johansen \& Juselius, 1990) in the multivariate framework. Let $Y_{t} \equiv$ $\left(s_{t}, m_{t}, m_{t}^{*}, y_{t}, y_{t}^{*}, r_{t}, r_{t}^{*}\right)$. If $Y_{t}$ is cointegated, this system can be generated by a vector error correction model.

$$
\Delta Y_{t}=\mu+\Pi \mathrm{Y}_{\mathrm{t}-1}+\sum_{i=1}^{p-1} \Gamma_{i} \Delta Y_{t-i}+\varepsilon_{t},
$$

where $\mu$ is a $7 \times 1$ vector of drift, $\Pi$ is a $7 \times 7$ matrices of parameters that captures the coefficients of the long-run relationship between variables, $\Gamma_{i}$ represents short-run dynamics, and $\varepsilon_{t}$ is white noise vector. Because $\Pi$ is an $n \times n(7 \times 7)$ matrix, $\Pi$ can be decomposed into two matrices $\alpha$ and $\beta$ (both $n$ $x r$ ) such that $\Pi=\alpha \cdot \beta^{\prime} . \alpha$ is the speed of adjustment to disequilibrium and $\beta$ is the matrix of cointegration vectors. The cointegrating relations depend on the $\operatorname{rank}(\Pi)$. Wedenotes the rank of $\Pi$ is $r(0 \leq r \leq 6)$. To identify the value of $r$, Johansen and Juselius (1990) and Johansen (1988) introduce Trace tests and $\lambda_{\text {max }}$ tests.

\footnotetext{
${ }^{2}$ Note that in sticky price model of Dornbusch, $\delta_{5}<0$ and $\delta_{6}>0$
} 
$\lambda_{\text {trace }}(r)=-T \sum_{i=r+1}^{n} \ln \left(1-\hat{\lambda}_{i}\right)$,

where $T$ is sample size, $\hat{\lambda}_{r+1}, \ldots \hat{\lambda}_{n}$ are smallest estimated eigenvalues. Trace statistic is employed to test the null hypothesis if there are at most $r$ cointegrating vectors against the alternative hypothesis of more than $r$ cointegrating vectors.

$$
\lambda_{\max }(r, r+1)=-T \ln \left(1-\hat{\lambda}_{r+1}\right) .
$$

The $\lambda_{\max }$ statistic tests the null hypothesis if there are at most $r$ cointegrating vectors against the alternative hypothesis of $r+1$ cointegrating vectors. If the results of two test statistics are not consistent, we will follow the trace statistic as suggested by Cheung and Lai (1993). The lag length is chosen based on the Schwarz information criterion (SIC).

\section{Data description and empirical results}

\subsection{Description of the data}

For Vietnam, the data begins from 1998:Q2 and ends in 2012:Q2. The sample period runs from 1998:Q4 to 2013:Q4 for the Indonesia, Thailand, Korea and Malaysia. Except for interest rates and inflation rates, all variables are presented in natural logarithms. The corresponding foreign variables are denoted by asterisks. The details about series are discussed below:

$s_{t}$ - Spot exchange rate - the price of one unit US dollar in terms of the selected Asian countries' currencies. For Vietnam, this variable is taken from State Bank of Vietnam while the other's exchange rates are extracted from International Financial Statistics (IFS).

$m_{t}-$ Money supply, in our study M2 is utilized as money supply and it is seasonally adjusted. This variable is collected from IFS for all economies.

$y_{t}$ - The real output. It is seasonally adjusted. In this study, real GDP is used for measuring output. For Vietnam, this variable is computed based on the data taken from General Statistics Office (GSO) and IFS. For other economies, data of real outputs are computed based on the data collected from IFS.

$r_{t}$ - Interest rate. Discount rates are used for estimating and they are extracted from IFS.

\subsection{Estimated results}

\subsubsection{Unit root tests}

Before turning to the VAR analysis, we test the stationarity property of the time series. The ADF (Augmented Dickey - Fuller) tests and PP (Phillips - Perron) tests indicate that all variables appear to be non-stationary in their levels, while they are stationary in their first differences for the case of Vietnam and the other economies (see the Appendix A for ADF and PP test results).

\subsubsection{Cointegration tests}

In the Johansen cointegration tests, the optimal lag length is chosen by applying the Schwarz information criterion. The results of cointegration tests are extracted from $\lambda_{\text {trace }}$ and $\lambda_{\text {max }}$ statistics and presented in Table 2 . 
Table 2

Cointegration tests

\begin{tabular}{|c|c|c|c|c|c|c|}
\hline$H_{0}$ & $\begin{array}{l}\text { Critical value } \\
(5 \%)\end{array}$ & Vietnam & Thailand & Korea & Indonesia & Malaysia \\
\hline \multicolumn{7}{|c|}{ Trace statistics } \\
\hline$r=0$ & 125.615 & $133.30^{* *}$ & $140.035^{*}$ & $186.265^{*}$ & $198.34^{*}$ & $249.217^{*}$ \\
\hline$r \leq 1$ & 95.753 & 86.901 & $95.835^{* *}$ & $121.900^{*}$ & $128.71^{*}$ & $118.166^{*}$ \\
\hline$r \leq 2$ & 69.818 & 57.773 & 64.000 & $75.701^{* *}$ & $82.351^{*}$ & $78.510^{*}$ \\
\hline$r \leq 3$ & 47.856 & 32.628 & 37.187 & 42.624 & 42.183 & 45.802 \\
\hline$r \leq 4$ & 29.797 & 17.864 & 19.841 & 20.163 & 11.923 & 21.045 \\
\hline$r \leq 5$ & 15.494 & 4.741 & 7.303 & 8.968 & 4.5948 & 8.7326 \\
\hline$r \leq 6$ & 3.8414 & 0.308 & 0.295 & 0.470 & 0.0522 & 0.0046 \\
\hline \multicolumn{7}{|c|}{ Max-eigenvalue statistics } \\
\hline$r=0$ & 46.231 & $46.399^{* *}$ & 44.199 & $64.365^{*}$ & $69.626^{*}$ & $131.05^{*}$ \\
\hline$r=1$ & 40.077 & 29.128 & 31.835 & $46.199^{*}$ & $46.362^{*}$ & 39.656 \\
\hline$r=2$ & 33.876 & 25.144 & 26.813 & 33.076 & $40.167^{*}$ & 32.707 \\
\hline$r=3$ & 27.584 & 14.764 & 17.345 & 22.460 & $30.259^{* *}$ & 24.756 \\
\hline$r=4$ & 21.131 & 13.122 & 12.537 & 11.194 & 7.3291 & 12.313 \\
\hline$r=5$ & 14.264 & 4.432 & 7.008 & 8.498 & 4.5425 & 8.727 \\
\hline$r=6$ & 3.8414 & 0.308 & 0.295 & 0.470 & 0.0522 & 0.0046 \\
\hline
\end{tabular}

Notes: ${ }^{*}$ and ${ }^{* *}$ are significant at $1 \%$ and $5 \%$ respectively. Lag length is chosen by SC.

It can be seen that the cointegration test results indicate the existence of one cointergating vector between monetary variables for Vietnam and at least one cointegrating vectors between exchange rate and its monetary fundamentals for the other economies in the sample.

\subsubsection{Monetary restriction tests}

The existence of cointegrating vectors between exchange rate and its relative monetary variables allow us to proceed to some underlying monetary restriction tests. The results are in Table 3.

\section{Table 3}

Results of monetary restriction test

\begin{tabular}{lllllll}
\hline & \multicolumn{1}{c}{ Vietnam } & \multicolumn{1}{c}{ Thai. } & \multicolumn{1}{c}{ Korea } & Indo. & Mal. \\
\hline$H_{1}$ & $4.80(0.09)$ & $10.44(0.0)$ & $59.84(0)$ & $48.00(0)$ & $63.84(0)$ \\
$H_{2}$ & $0.042(0.83)$ & $2.94(0.22)$ & $26.33(0)$ & $8.44(0)$ & $39.41(0)$ \\
$H_{3}$ & $6.63(0)$ & $17.74(0.41)$ & $18.28(0)$ & $8.54(0)$ & $91.12(0)$ \\
$H_{4}$ & $5.18(0.15)$ & $23.36(0)$ & $63.28(0)$ & $84.62(0)$ & $101.9(0)$ \\
$H_{5}$ & $12.82(0)$ & $27.40(0)$ & $78.70(0)$ & $63.41(0)$ & $127.6(0)$ \\
$H_{6}$ & $9.14(0)$ & $3.69(0.45)$ & $38.68(0)$ & $57.11(0)$ & $98.92(0)$ \\
$H_{7}$ & $12.93(0)$ & $32.73(0)$ & $83.86(0)$ & $99.04(0)$ & $144.5(0)$ \\
\hline
\end{tabular}

Notes: To facilitate readability, a significant level less than 0.05 of Chisq-statistics has been set zero.

Table 3 shows that, for Vietnam, the restrictions for money and output $\left(H_{1}, H_{2}, H_{4}\right)$ cannot be rejected. The null hypothesis $H_{1}$ cannot be rejected which indicates that there is of proportionality between Vietnamese dong- U.S dollar exchange rate and money supplies of Vietnam and the United States. In addition, the null hypothesis $\mathrm{H}_{2}$ and $\mathrm{H}_{4}$ cannot be rejected, thus we can conclude that the estimated coefficients of monetary and output are consistent with any of the forms of the monetary models.

For Thailand, the non-rejection is identified for output and interest rate $\left(\mathrm{H}_{2}, \mathrm{H}_{3}, \mathrm{H}_{6}\right)$, but the restriction for money $\left(H_{1}\right)$ is rejected. Moreover, for Korea, Indonesia, and Malaysia, all restrictions can be rejected. Therefore, for selected countries, with the exception of Vietnam, the proportionality between exchange rates and relative monies are rejected. 


\subsubsection{Exclusion restriction tests}

In order to make our findings more strictly, the exclusion restriction tests are performed. The results are expressed in Table 4.

Table 4

Results of exclusion restriction tests

\begin{tabular}{|c|c|c|c|c|c|}
\hline & Vietnam & Thai. & Korea & Indo. & Mal. \\
\hline$H_{8}$ & $14.79(0)$ & $3.65 \quad(0.16)$ & $25.92(0)$ & $5.40 \quad(0.14)$ & $30.54(0)$ \\
\hline$H_{9}$ & $17.25(0)$ & $10.66(0)$ & $55.42(0)$ & $50.27 \quad(0)$ & $39.34(0)$ \\
\hline$H_{10}$ & $12.79(0)$ & 20.10 & $63.36(0)$ & $50.34 \quad(0)$ & $67.60(0)$ \\
\hline$H_{11}$ & $8.31 \quad(0)$ & $9.65 \quad(0)$ & $36.35(0)$ & $51.94 \quad(0)$ & $105.3(0)$ \\
\hline
\end{tabular}

Notes: To facilitate readability, a significant level less than 0.05 of Chisq-statistics has been set zero.

Table 4 shows that for the case of Vietnam, none of these variables is excluded in forming the cointegrating relationship. Similarity, for Korea and Malaysia, all exclusion restrictions can be rejected. On the contrary, for Thailand and Indonesia, exclusion restriction tests demonstrate that exchange rates are not a part of the cointegration relationships.

\subsubsection{Long - run relationship and short - run dynamic}

As mentioned previously, for Thailand and Indonesion, the results of exclusion restriction test implies that the monetary model is not valid framework for the long-run exchange rate beetwen Thai baht - U.S dollar exchange rate as well as Indonesian rupiah - U.S dollar exchange rate. For Vietnam, some money restrictions cannot be rejected and all the null hypotheses of exclusion restrictions are rejected. We then re-estimate the cointegrating relationship by imposing monetary restrictions $H_{1}$ and $H_{2}$. The restriction cannot be rejected and the long-run relationship is presented in Eq. (5).

$$
S_{t}=\left(m_{t}-m_{t}^{*}\right)-3.11\left(y_{t}-y_{t}^{*}\right)-0.0002 r_{t}-0.037 r_{t}^{*}
$$

From a technical standpoint, simulating VARs can be used for forecasting dynamic system of equations (Richard, 2015). Therefore, this paper uses simulating VARs to make dynamic forecasts for Vietnamese dong - US dollar exchange rate $(s)$. Fig. 1 shows the forecasted values follow closely with the actual values' movement, indicating that the model fits the data appropriately.

$\mathrm{s}$

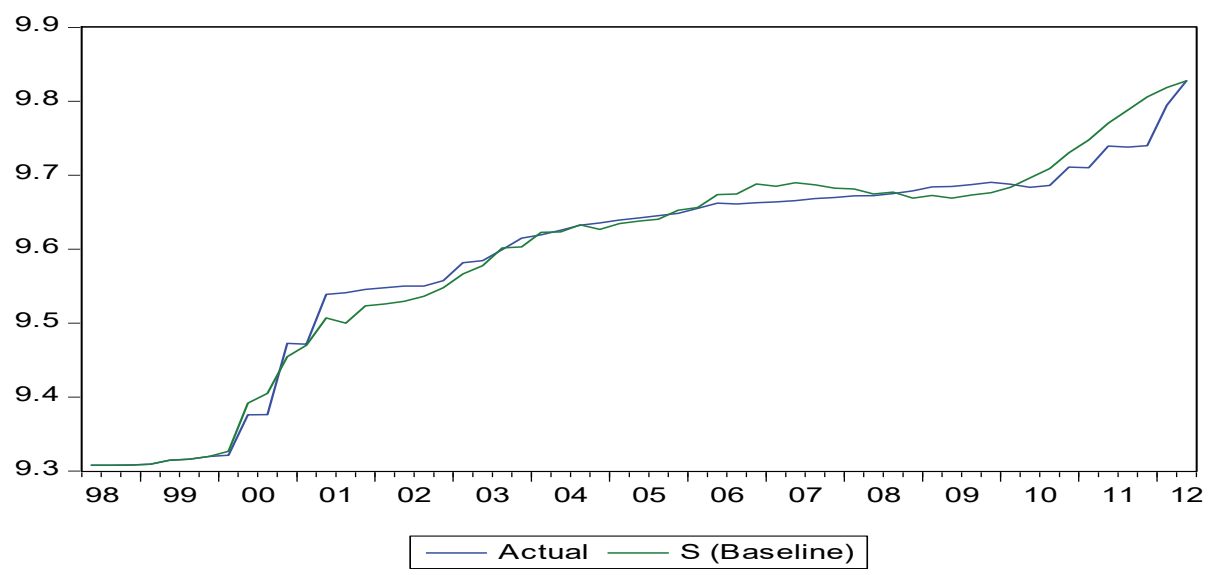

Fig. 1. Actual and Forecasted values of Vietnamese dong-US dollar exchange rate

For Korea and Malaysia, it is worth recalling that the hypothesis of proportionality between exchange rates and relative money supplies are rejected. Moreover, the sign of estimated coefficients in all cointegration vectors are not consistent with any variant of monetary model (see Appendix B). 


\section{Discussion}

The estimated result of monetary approach to exchange rate determination for a group of Pacific Basin countries has revealed several important findings. For Thailand, although estimated results demonstrate the existence of long-run relationships between exchange rate and its fundamentals, the long-run relationships is not supported by exclusion tests. Indeed, the null hypothesis $H_{8}$ cannot be rejected suggesting that the Thai baht - U.S dollar exchange rate is not a part of long-run relationship. Therefore, it can be concluded that this monetary model does not work to explain the movement of the Thai baht - U.S dollar exchange rate in period of study. This results contrast sharply with the findings in the previous study by V. K.-S. Liew, Baharumshah, and Puah (2009). Considering the Indonesia, the estimated results carry the same meaning to Thailand's. In this case, there is existence of long-run relationship between Indonesian rupiah - U.S dollar exchange rate and its relative fundamentals. However, the cointegrating relationships are not supported by the exclusion restriction on exchange rate, implying that exchange rate is not a part of cointegrating vectors. For this reason, it is reasonable to conclude that the monetary model has not performed well to explain the Indonesian rupiah - U.S dollar exchange rate in period of study. Regarding to Korea, the estimated results express that there is a valid framework for analyzing long-run movement in Korea won- U.S dollar exchange rates. The cointegration relationships between Korea won- U.S dollar exchange rate and its relative fundamentals including money supply, output and interest rate are supported by the exclusion tests: none of these variables are excluded. However, the hypothesis of proportionality between exchange rate and money supply is rejected for period of the study. These findings are in accordance with those of Makrydakis (1998) and Miyakoshi (2000) who used data for pre-Asian financial crisis periods.

Referring to the case of Malaysia, the estimated result reflects the existence of cointegrating relationship between Malaysian ringgit-U.S dollar exchange rate and its relative monetary fundamentals including money supply, output and interest rate. The result is supported by the exclusion restriction tests $H_{8}, H_{9}, H_{10}, H_{11}$, all these hypotheses can be rejected. However, the rejection of $H_{1}$ also indicates that Malaysian ringgit-U.S. dollar exchange rate does not respond proportionally to changes in monies, implying that there is no variant of monetary model reasonably explains exchange rate movements. This result contracts sharply with the findings of Chin et al. (2007a) who gave the evidence that strongly supports Bilson's monetary model. Concerning the empirical observation from Vietnam, the country was less affected by Asian financial crisis, estimated result reports the existence of long-run relationship between Vietnamese dong-U.S dollar exchange rate and its fundamentals. The cointegrating relationship is supported by the result of exclusion restriction tests. Particularly, the result of monetary restriction test, the null hypothesis $H_{1}$ cannot be rejected, implies that there is existence of proportionality between the Vietnamese dong-U.S dollar exchange rate and money supply of Vietnam and the United States. Moreover, the null hypothesis $H_{2}$ cannot be rejected. As a result, the estimated coefficients of monetary and output are consistent with any of the forms of the monetary models. However, the sign of estimated coefficients of interest rate are mixed: the sign of domestic interest rate accords with Dornbusch's form while the sign of coefficient of U.S interest rate is consistent with Bilson's one'.

\section{Conclusion}

This paper has examined how well monetary fundamentals could explain the movement in the bilateral nominal exchange rate of Vietnamese dong, Thai baht, Korean won, Indonesian rupiah, and Malaysian ringgit with respect to US dollar. Using quarterly data for the period of post Asian financial crisis and Johansen - Juselius cointegration techniques, the empirical results are mixed. For Thailand and Indonesia, exchange rates are found to be not a part of cointegrating vectors between them and their

\footnotetext{
${ }^{3}$ It is worth recalling that in Bilson's model, the domestic (foreign) interest rate has a positive (negative) influence on exchange rate. Conversely, in Dornbusch's model, the sign of estimated coefficient for domestic (foreign) interest rate is expected to be negative (positive).
} 
relative monetary fundamentals. For Korea and Malaysia, although the monetary model provides valid framework for analysing the long-run movements in the exchange rates, the proportionality hypothesis of exchange rate and its relative monies does not hold. Conversely, for Vietnam, the monetary model is valid for explaining the long-run nominal exchange rate between the Vietnamese dong and US dollar. Importantly, the estimated coefficients of money and output variables are consistent with any traditional variant of monetary model. The estimated results in this paper, in sharp contrast to the findings of earlier literature on the subject (Chin et al., 2007a; Liew et al., 2009) but they are consistent with those reached by Miyakoshi (2000), as well as the findings for the case of Vietnam and the Indonesia, for the first time, induce researchers to reconsider the models in future studies.

\section{Acknowledgements}

We would like to thank Gilles Dufrenot and Marcel Aloy for helpful comments. Any remaining errors are ours.

\section{References}

Alvarez, F., Atkeson, A., \& Kehoe, P. J. (2007). If exchange rates are random walks, then almost everything we say about monetary policy is wrong. American Economic Review, 97(2), 339-345.

Baillie, R. T., \& Selover, D. D. (1987). Cointegration and models of exchange rate determination. International Journal of Forecasting, 3(1), 43-51.

Bilson, J. F. (1978). The monetary approach to the exchange rate: some empirical evidence. IMF Staff Papers, 25(1), 48-75.

Boothe, P., \& Glassman, D. (1987). Off the mark: lessons for exchange rate modelling. Oxford Economic Papers, 39(3), 443-457.

Cheung, Y.-W. C., Menzie D; Pascual, Antonio Garcia. (2005). Empirical exchange rate models of the nineties: Are any fit to survive? Journal of International Money and Finance, 24(7), 1150-1175.

Cheung, Y. W., \& Lai, K. S. (1993). Finite-sample sizes of Johansen's likelihood ratio tests for cointegration. Oxford Bulletin of Economics and statistics, 55(3), 313-328.

Chin, L., Azali, M., \& Matthews, K. G. (2007a). The monetary approach to exchange rate determination for Malaysia. 3(2), 91-94.

Chin, L. A., M; Matthews, KG. (2007a). The monetary approach to exchange rate determination for Malaysia. Applied Financial Economics Letters, 3(2), 91-94.

Chin, L. A., M;Yusop, Zulkornain B; Yusoff, Mohammed B. (2007b). The monetary model of exchange rate: evidence from The Philippines. Applied Economics Letters, 14(13), 993-997.

Chinn, M. D., \& Meese, R. A. (1995). Banking on currency forecasts: How predictable is change in money? Journal of International Economics, 38(1), 161-178.

Cushman, D. O. (2007). A portfolio balance approach to the Canadian-US exchange rate. Review of Financial Economics, 16(3), 305-320.

Diamandis, P. F., Georgoutsos, D. A., \& Kouretas, G. P. (1998). The monetary approach to the exchange rate: long-run relationships, identification and temporal stability. Journal of Macroeconomics, 20(4), 741-766.

Dornbusch, R. (1976). Expectations and exchange rate dynamics. The Journal of Political Economy, 84(6), 1161-1176.

Engel, C., Mark, N. C., West, K. D., Rogoff, K., \& Rossi, B. (2007). Exchange rate models are not as bad as you think [with comments and discussion]. NBER Macroeconomics Annual, 22, 381-473.

Faust, J. R., John H; H Wright, Jonathan. (2003). Exchange rate forecasting: the errors we've really made. Journal of International Economics, 60(1), 35-59.

Frankel, J. A. (1979). On the mark: A theory of floating exchange rates based on real interest differentials. The American Economic Review, 69(4), 610-622.

Frenkel, J. A. (1976). A monetary approach to the exchange rate: doctrinal aspects and empirical evidence. The Scandinavian Journal of Economics, 78(2), 200-224. 
Frenkel, M., \& Koske, I. (2004). How well can monetary factors explain the exchange rate of the euro? Atlantic Economic Journal, 32(3), 233-244.

Hwang, J. K. (2001). Dynamic forecasting of monetary exchange rate models: evidence from cointegration. International Advances in Economic Research, 7(1), 51-64.

Johansen, S. (1988). Statistic analysis of cointegration vectors. Journal of Economics Dynamics and Control, 12, 231-254.

Johansen, S. (1988). Statistical analysis of cointegration vectors. Journal of Economic Dynamics and Control, 12(2-3), 231-254.

Johansen, S., \& Juselius, K. (1990). Maximum likelihood estimation and inference on cointegrationwith applications to the demand for money. Oxford Bulletin of Economics and statistics, 52(2), 169210.

Kouretas, G. P. (1997). Identifying linear restrictions on the monetary exchange rate model and the uncovered interest parity: cointegration evidence from the Canadian-US dollar. Canadian Journal of Economics, 30(4a), 875-890.

Liew, V. K. S., Baharumshah, A. Z., \& Puah, C. H. (2009). Monetary model of exchange rate for Thailand: long-run relationship and monetary restrictions. Global Economic Review, 38(4), 385395.

Liew, V. K.-S. B., Ahmad Zubaidi; Puah, Chin-Hong. (2009). Monetary model of exchange rate for Thailand: long-run relationship and monetary restrictions. Global Economic Review, 38(4), 385395.

Loría, E., Sánchez, A., \& Salgado, U. (2010). New evidence on the monetary approach of exchange rate determination in Mexico 1994-2007: A cointegrated SVAR model. Journal of International Money and Finance, 29(3), 540-554.

MacDonald, R., \& Taylor, M. P. (1991). The monetary approach to the exchange rate: long-run relationships and coefficient restrictions. Economics Letters, 37(2), 179-185.

MacDonald, R., \& Taylor, M. P. (1993). The monetary approach to the exchange rate: rational expectations, long-run equilibrium, and forecasting. Staff Papers, 40(1), 89-107.

MacDonald, R., \& Taylor, M. P. (1994a). The monetary model of the exchange rate: long-run relationships, short-run dynamics and how to beat a random walk. Journal of International Money and Finance, 13(3), 276-290.

MacDonald, R., \& Taylor, M. P. (1994b). Reexamining the monetary approach to the exchange rate: the dollar-franc, 1976-90. Applied Financial Economics, 4(6), 423-430.

Makrydakis, S. (1998). Testing the long-run validity of the monetary approach to the exchange rate: the won-US dollar case. Applied Economics Letters, 5(8), 507-511.

Mark, N. C. (1995). Exchange rates and fundamentals: Evidence on long-horizon predictability. The American Economic Review, 201-218.

Meese, R. A. (1986). Testing for bubbles in exchange markets: A case of sparkling rates? The Journal of Political Economy, 94(2), 345-373.

Meese, R. A., \& Rogoff, K. (1983). Empirical exchange rate models of the seventies: do they fit out of sample? Journal of International Economics, 14(1), 3-24.

Miyakoshi, T. (2000). The monetary approach to the exchange rate: empirical observations from Korea. Applied Economics Letters, 7(12), 791-794.

Miyakoshi, T. (2000). The monetary approach to the exchange rate: empirical observations from Korea. Applied Economics Letters, 7(12), 791-794.

Papadamou, S., \& Markopoulos, T. (2012). The monetary approach to the exchange rate determination for a "Petrocurrency": The case of Norwegian Krone. International Advances in Economic Research, 18(3), 299-314.

Rapach, D. E., \& Wohar, M. E. (2002). Testing the monetary model of exchange rate determination: new evidence from a century of data. Journal of International Economics, 58(2), 359-385.

Richard, S. (2015). Eviews illustrated for Version 9. In M. S. a. I. G. Inc (Ed.).

Tawadros, G. B. (2008). A structural time series test of the monetary model of exchange rates under four big inflations. Economic Modelling, 25(6), 1216-1224. 
Uz, I., \& Ketenci, N. (2008). Panel analysis of the monetary approach to exchange rates: Evidence from ten new EU members and Turkey. Emerging Markets Review, 9(1), 57-69.

\section{Appendix}

Appendix A

Table 5

Unit root tests- Vietnam

\begin{tabular}{|c|c|c|c|c|c|c|c|c|}
\hline \multirow[b]{3}{*}{ Variable } & \multicolumn{4}{|c|}{ Augmented Dickey - Fuller tests } & \multicolumn{4}{|c|}{ Phillips - Perron tests } \\
\hline & \multicolumn{2}{|c|}{ Intercept } & \multicolumn{2}{|c|}{ Intercept + trend } & \multicolumn{2}{|c|}{ Intercept } & \multicolumn{2}{|c|}{$\underline{\text { Intercept }}+$ trend } \\
\hline & Level & $1^{\text {st }} \operatorname{diff}$ & Level & $1^{\text {st }} \operatorname{diff}$ & Level & $1^{\text {st }}$ diff & Level & $1^{\text {st }} \operatorname{diff}$ \\
\hline$S$ & -0.52 & $-4.01^{*}$ & -1.47 & $-3.98^{* *}$ & -0.55 & $-9.02^{*}$ & -1.61 & $-8.95^{*}$ \\
\hline$m_{t}$ & -1.05 & $-5.57^{*}$ & -1.90 & $-5.64^{*}$ & -0.93 & $-5.57^{*}$ & -1.53 & $-5.59^{*}$ \\
\hline$m_{t}^{*}$ & -0.23 & $-5.97^{*}$ & -2.29 & $-5.92^{*}$ & -0.23 & $-5.97^{*}$ & -2.06 & $-5.92^{*}$ \\
\hline$y_{t}$ & -1.16 & $-11.21^{*}$ & -2.41 & $-11.23^{*}$ & -2.63 & $-13.80^{*}$ & -3.20 & $-17.72^{*}$ \\
\hline$y_{t}^{*}$ & -2.24 & $-4.85^{*}$ & -1.66 & $-5.22^{*}$ & $-2.98^{* *}$ & $-4.74^{*}$ & -1.81 & $-5.16^{*}$ \\
\hline$r$ & -2.94 & $-5.79^{*}$ & -2.63 & $-6.36^{*}$ & -2.49 & $-6.37^{* *}$ & -1.83 & $-8.01^{*}$ \\
\hline$r_{t}^{*}$ & -1.64 & $-3.97^{* *}$ & -2.50 & $-3.94^{* *}$ & -1.34 & $-4.08^{* *}$ & -2.12 & $-4.05^{* *}$ \\
\hline $\begin{array}{l}\text { es: }{ }^{*} \text { an } \\
\text { rion. } \\
\text { series a }\end{array}$ & & & & & & & & \\
\hline
\end{tabular}

Table 6

Unit root tests- Thailand

\begin{tabular}{|c|c|c|c|c|c|c|c|c|}
\hline \multirow{3}{*}{ Variable } & \multicolumn{4}{|c|}{ Augmented Dickey - Fuller tests } & \multicolumn{4}{|c|}{ Phillips - Perron tests } \\
\hline & \multicolumn{2}{|c|}{ Intercept } & \multicolumn{2}{|c|}{ Intercept + trend } & \multicolumn{2}{|c|}{ Intercept } & \multicolumn{2}{|c|}{ Intercept + trend } \\
\hline & Level & $1^{\text {st }}$ diff & Level & $1^{\text {st }} \operatorname{diff}$ & Level & $1^{1^{\text {st }}}$ diff & Level & $1^{\text {st }}$ diff \\
\hline$S$ & -0.54 & $-5.24^{*}$ & -3.07 & $-5.33^{*}$ & -0.61 & $-5.36^{*}$ & -2.65 & $-5.35^{*}$ \\
\hline$m_{t}$ & 1.87 & $-6.64^{*}$ & -1.15 & $-6.95^{*}$ & 1.85 & $-6.65^{*}$ & -1.26 & $-6.93^{*}$ \\
\hline$m_{t}^{*}$ & -0.22 & $-5.89^{*}$ & -2.59 & $-5.84^{*}$ & -0.22 & $-5.87^{*}$ & -2.23 & $-5.82^{*}$ \\
\hline$y_{t}$ & -1.05 & $-10.19^{*}$ & -3.00 & $-10.16^{*}$ & -1.31 & $-11.34^{*}$ & -2.84 & $-11.98^{*}$ \\
\hline$y_{t}^{*}$ & -1.41 & $-4.91^{*}$ & -2.00 & $-4.96^{*}$ & -1.63 & $-4.82^{*}$ & -1.97 & $-4.98^{*}$ \\
\hline$r$ & -2.19 & $-10.06^{*}$ & -2.24 & $-9.58^{*}$ & $-6.14^{*}$ & $-9.99^{*}$ & $-5.89^{*}$ & $-9.52^{*}$ \\
\hline$r_{t}^{*}$ & -2.34 & $-3.22^{* *}$ & $-3.24^{* * *}$ & $-3.19^{* * *}$ & -1.64 & $-4.69^{*}$ & -2.03 & $-4.65^{*}$ \\
\hline
\end{tabular}

Notes: $* * *$ and $* * *$ are significant at $1 \%, 5 \%$ and $10 \%$ respectively

Table 7

Unit root tests- Korea

\begin{tabular}{|c|c|c|c|c|c|c|c|c|}
\hline \multirow{3}{*}{ Variable } & \multicolumn{4}{|c|}{ Augmented Dickey - Fuller tests } & \multicolumn{4}{|c|}{ Phillips - Perron tests } \\
\hline & \multicolumn{2}{|c|}{ Intercept } & \multicolumn{2}{|c|}{ Intercept + trend } & \multicolumn{2}{|c|}{ Intercept } & \multicolumn{2}{|c|}{$\underline{\text { Intercept }}+$ trend } \\
\hline & Level & $1^{\text {st }}$ diff & Level & $1^{\text {st }}$ diff & Level & $1^{\text {st }}$ diff & Level & $1^{\text {st }}$ diff \\
\hline$S$ & -2.49 & $-5.50^{*}$ & -2.62 & $-5.43^{*}$ & -2.27 & $-5.48^{*}$ & -2.28 & $-5.40^{*}$ \\
\hline$m_{t}$ & -0.61 & $-6.11^{*}$ & -0.91 & $-6.05^{*}$ & -0.55 & $-6.21^{*}$ & -1.37 & $-6.15^{*}$ \\
\hline$m_{t}^{*}$ & -0.22 & $-5.89^{*}$ & -2.59 & $-5.84^{*}$ & -0.22 & $-5.87^{*}$ & -2.23 & $-5.82^{*}$ \\
\hline$y_{t}$ & -3.00 & $-6.70^{*}$ & -3.66 & $-7.27^{*}$ & $-2.97^{* *}$ & $-6.70^{*}$ & $-3.38^{* * *}$ & $-7.29^{*}$ \\
\hline$y_{t}^{*}$ & -1.41 & $-4.91^{*}$ & -2.00 & $-4.96^{*}$ & -1.63 & $-4.82^{*}$ & -1.97 & $-4.98^{*}$ \\
\hline$r$ & -2.05 & $-5.58^{*}$ & $-3.34^{* * *}$ & $-5.50^{*}$ & $-2.97^{* *}$ & -5.29 & $-3.42^{* * *}$ & $-5.15^{*}$ \\
\hline$r_{t}^{*}$ & -2.34 & $-3.22^{* *}$ & $-3.24^{* * *}$ & $-3.19^{* * *}$ & -1.64 & $-4.69^{*}$ & -2.03 & $-4.65^{*}$ \\
\hline
\end{tabular}

Notes: $* * *$ and $* * *$ are significant at $1 \%, 5 \%$ and $10 \%$ respectively 
Table 8

Unit root tests - Malaysia

\begin{tabular}{|c|c|c|c|c|c|c|c|c|}
\hline \multirow{3}{*}{ Variable } & \multicolumn{4}{|c|}{ Augmented Dickey - Fuller tests } & \multicolumn{4}{|c|}{ Phillips - Perron tests } \\
\hline & \multicolumn{2}{|c|}{ Intercept } & \multicolumn{2}{|c|}{ Intercept + trend } & \multicolumn{2}{|c|}{ Intercept } & \multicolumn{2}{|c|}{ Intercept + trend } \\
\hline & Level & $1^{\text {st }}$ diff & Level & $1^{\text {st }}$ diff & Level & $1^{\text {st }}$ diff & Level & $1^{\text {st }}$ diff \\
\hline$S$ & -0.72 & $-5.95^{*}$ & -2.72 & $-5.90^{*}$ & -0.84 & $-5.92^{*}$ & -2.31 & $-5.87^{*}$ \\
\hline$m_{t}$ & 0.07 & $-5.02^{*}$ & -1.92 & $-4.99^{*}$ & 0.04 & $-5.11^{*}$ & -1.73 & $-5.08^{*}$ \\
\hline$m_{t}^{*}$ & -0.22 & $-5.89^{*}$ & -2.59 & $-5.84^{*}$ & -0.22 & $-5.87^{*}$ & -2.23 & $-5.82^{*}$ \\
\hline$y_{t}$ & -0.52 & $-5.64^{*}$ & $-3.62^{* *}$ & $-5.56^{*}$ & -1.25 & $-5.50^{*}$ & $-3.49^{* *}$ & $-5.40^{*}$ \\
\hline$y_{t}^{*}$ & -1.41 & $-4.91^{*}$ & -2.00 & $-4.96^{*}$ & -1.63 & $-4.82^{*}$ & -1.97 & $-4.98^{*}$ \\
\hline$r$ & $-6.7^{*}$ & $-11.1^{*}$ & $-6.72^{*}$ & $-10.4^{*}$ & $-5.48^{*}$ & $-4.19^{*}$ & $-5.29^{*}$ & $-4.27^{*}$ \\
\hline$r_{t}^{*}$ & -2.34 & $-3.22^{* *}$ & $-3.24^{* * *}$ & $-3.19^{* * *}$ & -1.64 & $-4.69^{*}$ & -2.03 & $-4.65^{*}$ \\
\hline
\end{tabular}

Notes: $* * *$ and $* * *$ are significant at $1 \%, 5 \%$ and $10 \%$ respectively. The domestic interest rate is $\mathrm{I}(0)$. It is assumed, however, that it is I(1).

Table 9

Unit root tests - The Indonesia

\begin{tabular}{|c|c|c|c|c|c|c|c|c|}
\hline \multirow{3}{*}{ Variable } & \multicolumn{4}{|c|}{ Augmented Dickey - Fuller tests } & \multicolumn{4}{|c|}{ Phillips - Perron tests } \\
\hline & \multicolumn{2}{|c|}{ Intercept } & \multicolumn{2}{|c|}{ Intercept + trend } & \multicolumn{2}{|c|}{ Intercept } & \multicolumn{2}{|c|}{ Intercept + trend } \\
\hline & Level & $1^{\text {st }}$ diff & Level & $1^{\text {st }}$ diff & Level & $1^{\text {st }}$ diff & Level & $1^{\text {st }} \operatorname{diff}$ \\
\hline$S$ & -2.57 & $-7.34^{*}$ & -2.76 & $-7.26^{*}$ & -2.69 & $-7.34^{*}$ & -2.98 & $-7.27^{*}$ \\
\hline$m_{t}$ & 1.84 & $-3.03^{* *}$ & -0.88 & $-9.70^{*}$ & 1.99 & $-8.78^{*}$ & -0.82 & $-9.49^{*}$ \\
\hline$m_{t}^{*}$ & -1.99 & $-5.84^{*}$ & -2.57 & $-5.79^{*}$ & -0.20 & $-5.82^{*}$ & -2.22 & $-5.77^{*}$ \\
\hline$y_{t}$ & -0.45 & $-6.34^{*}$ & -1.50 & $-6.30^{*}$ & -0.46 & $-6.44^{*}$ & -1.89 & $-6.40^{*}$ \\
\hline$y_{t}^{*}$ & -1.41 & $-4.83^{*}$ & -1.98 & $-4.88^{*}$ & -1.69 & $-4.74^{*}$ & -1.94 & $-4.80^{*}$ \\
\hline$r$ & $-7.93^{*}$ & $-4.46^{*}$ & -4.46 & $-4.75^{*}$ & $-5.34^{*}$ & $-4.46^{*}$ & $-5.39^{*}$ & $-4.89^{*}$ \\
\hline$r_{t}^{*}$ & -2.74 & $-3.01^{* *}$ & $-3.28^{* * *}$ & -2.98 & -1.63 & $-4.65^{*}$ & -2.01 & $-4.61^{*}$ \\
\hline
\end{tabular}

Notes: $* * *$ and $* * *$ are significant at $1 \%, 5 \%$ and $10 \%$ respectively. The domestic interest rate is $\mathrm{I}(0)$. It is assumed, however, that it is I(1).

Appendix B

Table 10

Cointegrating vectors of Korea and Malaysia

\begin{tabular}{lcccccccc}
\hline & $s_{t}$ & $m_{t}$ & $m_{t}^{*}$ & $y_{t}$ & $y_{t}^{*}$ & $r_{t}$ & $r_{t}^{*}$ & \multicolumn{1}{c}{ Const } \\
\hline Korea & & & & & & & & \\
& 1 & 5.47 & -0.41 & -23.48 & 25.48 & -83.07 & 10.46 & 8.34 \\
& 1 & -7.73 & -2.52 & 31.67 & -23.05 & 25.71 & 15.65 & -85.36 \\
& 1 & 5.18 & -0.003 & -17.08 & 15.08 & 28.55 & -17.64 & 10.15 \\
Malaysia & & & & & & & & \\
& 1 & -4.674 & -12.921 & 33.10 & -15.82 & -19.78 & 0.189 & 104 \\
& 1 & -0.101 & 2.77 & -9.73 & 24.32 & -156.25 & 10.24 & -169 \\
& 1 & 1.439 & -0.99 & 4.19 & -21.63 & 153.36 & -11.08 & 149 \\
\hline
\end{tabular}




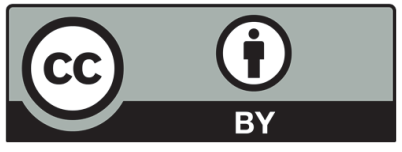

(C) 2020 by the authors; licensee Growing Science, Canada. This is an open access article distributed under the terms and conditions of the Creative Commons Attribution (CC-BY) license (http://creativecommons.org/licenses/by/4.0/). 